\title{
Optical Imaging Reveals Elevated Intracellular Chloride in Hippocampal Pyramidal Neurons after Oxidative Stress
}

\author{
Renu Sah and Rochelle D. Schwartz-Bloom \\ Department of Pharmacology and Cancer Biology, Duke University Medical Center, Durham, North Carolina 27710
}

The accumulation of reactive oxygen species (ROS) in the brain is associated with several neurodegenerative conditions. ROS can affect ionic homeostasis leading to impaired neurotransmission. Here, we determined the ability of $\mathrm{H}_{2} \mathrm{O}_{2}$, a membrane permeant ROS, to alter intraneuronal $\mathrm{Cl}^{-}$, an important regulator of neuronal excitability. Real-time alterations in intracellular chloride, $\left[\mathrm{Cl}^{-}\right] \mathrm{i}$, were measured with UV laser scanning confocal microscopy in hippocampal slices loaded with the cell-permeant form of 6-methoxy- $N$-ethylquinolium iodide (MEQ), a $\mathrm{Cl}^{-}$-sensitive fluorescent probe. In slices superfused with $\mathrm{H}_{2} \mathrm{O}_{2}$ for 10 min, there was a significant decrease in MEQ fluorescence (elevation in $\left[\mathrm{Cl}^{-}\right] \mathrm{i}$ ) in area CA1 pyramidal cell soma but not in interneurons located in stratum radiatum. Alterations in $\left[\mathrm{Cl}^{-}\right] \mathrm{i}$ induced by $\mathrm{H}_{2} \mathrm{O}_{2}$ were prevented by the iron chelator deferoxamine and the vitamin $\mathrm{E}$ analog Trolox, suggesting the involvement of free radicals. The influx of $\mathrm{Cl}^{-}$ probably occurred through the GABA-gated $\mathrm{Cl}^{-}$channel be-

Reactive oxygen species (ROS) are byproducts generated by cellular oxidative metabolism. However, enhanced production of ROS, exceeding the intrinsic antioxidant scavenging capacity, leads to the development of several pathophysiological conditions. Brain tissue may be especially vulnerable to ROS damage because of high oxygen consumption, moderate antioxidant capacity, and membranes rich in easily oxidized polyunsaturated lipids. Mounting evidence has implicated the role of ROS in the pathophysiology of neurodegenerative conditions such as Parkinson's disease, Huntington's disease, Alzheimer's disease, and in normal aging (for review, see Beal, 1995; Simonian and Coyle, 1996). An essential component of ROS-induced neurotoxicity may involve the modulation of various ion transport proteins and receptor-gated ion channels either directly via protein oxidation or indirectly via peroxidation of membrane phospholipids (Kourie, 1998).

The effect of ROS on synaptic transmission has been examined previously in the hippocampal slice. With exposure to oxygen free radicals, synaptic efficacy and the ability to generate spikes are impaired (Pellmar et al., 1989). EPSPs have been shown to be reduced (Pellmar, 1995) or enhanced (Frantseva et al., 1998) in

\footnotetext{
Received May 6, 1999; revised Aug. 2, 1999; accepted Aug. 12, 1999.

This work was supported by National Institutes of Health Grants 5 T32 AG00029 (R.S.) and NS28791 (R.D.S.). We gratefully acknowledge the laboratory of Dr. J. Victor Nadler for analysis of HPLC samples and Dr. George Somjen for helpful comments on this manuscript.

Correspondence should be addressed to Dr. Rochelle D. Schwartz-Bloom, Department of Pharmacology and Cancer Biology, Box 3813, Duke University Medical Center, Durham, NC 27710. E-mail: schwa001@duke.edu.

Copyright (C) 1999 Society for Neuroscience 0270-6474/99/199209-09\$05.00/0
}

cause the effects of $\mathrm{H}_{2} \mathrm{O}_{2}$ were blocked by picrotoxin. In addition, HPLC analysis of the superfusates indicated that GABA and glutamate accumulated extracellularly after $\mathrm{H}_{2} \mathrm{O}_{2}$ exposure. Excitatory amino acid receptor antagonists 2-amino-5-phoshopentanoic acid and 1,2,3,4-tetrahydro-6nitro-2, 3-dioxo-benzo[f]quinoxaline-7-sulfonamide also attenuated the effect of $\mathrm{H}_{2} \mathrm{O}_{2}$ on $\mathrm{MEQ}$ fluorescence. The changes in $\left[\mathrm{Cl}^{-}\right] \mathrm{i}$ induced by $\mathrm{H}_{2} \mathrm{O}_{2}$ were $\mathrm{Ca}^{2+}$-dependent and $\mathrm{Na}^{+}$-independent. After exposure of slices to $\mathrm{H}_{2} \mathrm{O}_{2}$, the ability of the GABA agonist muscimol to increase $\left[\mathrm{Cl}^{-}\right] \mathrm{i}$ was attenuated. Thus, ROS, like $\mathrm{H}_{2} \mathrm{O}_{2}$, may impair transmembrane $\mathrm{Cl}^{-}$gradients and reduce inhibitory neurotransmission, further promoting neuronal damage in oxidative stressrelated disease and in aging.

Key words: oxidative stress; intracellular chloride; hippocampal neurons; imaging; $\mathrm{H}_{2} \mathrm{O}_{2} ; \mathrm{GABA}$

neurons exposed to ROS. However, IPSPs were significantly reduced in both of these studies. Presynaptic and postsynaptic mechanisms have been implicated in the alteration of synaptic function by ROS (Colton et al., 1989; Pellmar, 1995), although specific targets have not been identified.

The sensitivity of inhibitory neurotransmission (i.e., GABAergic neurotransmission) to oxidative stress may be particularly important because a reduction in neuronal inhibition can lead to neuronal excitability. Previously, we reported that the generation of superoxide radicals in cerebral cortical synaptoneurosomes reduced $\mathrm{GABA}_{\mathrm{A}}$ receptor activity (Schwartz et al., 1988). In addition, we have demonstrated an increase in intracellular chloride $\left(\left[\mathrm{Cl}^{-}\right] \mathrm{i}\right)$ and a subsequent reduction in $\mathrm{GABA}_{\mathrm{A}}$ responses in hippocampal neurons after in vitro ischemia (oxygen-glucose deprivation) (Inglefield and Schwartz-Bloom, 1998). Previous reports indicate that alterations in $\mathrm{GABA}_{\mathrm{A}}$ receptor-mediated inhibition may underlie hydrogen peroxide $\left(\mathrm{H}_{2} \mathrm{O}_{2}\right)$-induced changes in synaptic transmission (Katsuki et al., 1997). However, little is known about the effects of ROS on intracellular $\mathrm{Cl}^{-}$ levels and $\mathrm{GABA}_{\mathrm{A}}$ receptor activity in an intact neuronal system.

Here, using optical imaging techniques and fluorescent dyes, we investigated the ability of $\mathrm{H}_{2} \mathrm{O}_{2}$, a membrane-permeant ROS, to affect intracellular $\mathrm{Cl}^{-}$in hippocampal area CA1 pyramidal neurons and interneurons. Our working hypothesis was that ROS can perturb transmembrane $\mathrm{Cl}^{-}$gradients within hippocampal neurons, resulting in reduced $\mathrm{GABA}_{\mathrm{A}}$ responses. We observed that exogenous $\mathrm{H}_{2} \mathrm{O}_{2}$ caused a $\mathrm{Ca}^{2+}$-dependent increase in intracellular $\mathrm{Cl}^{-}$in area CA1 pyramidal neurons of the hippocampus, followed by a reduction in $\mathrm{GABA}_{\mathrm{A}}$ responses. We suggest that impairment of $\mathrm{Cl}^{-}$gradients by $\mathrm{H}_{2} \mathrm{O}_{2}$ could reduce $\mathrm{GABA}_{\mathrm{A}}$ 
receptor-mediated inhibitory transmission and promote neuronal damage in a variety of neurodegenerative conditions.

Part of this paper has been published previously in abstract form (Sah and Schwartz-Bloom, 1999).

\section{MATERIALS AND METHODS}

Materials. 6-methoxy- $N$-ethylquinolium iodide, (MEQ), carboxydichlorodihydrofluoresein diacetate ( $\left.\mathrm{c}-\mathrm{H}_{2} \mathrm{DCFDA}\right)$, and propidium iodide were purchased from Molecular Probes (Eugene, OR). Trolox was obtained from Fluka BioChemika (Ronkonkoma, NY). D-2-amino-5phosphopentanoic acid (D-AP-5) was obtained from Tocris Cookson (Ballwin, MO). Tiagabine and 1,2,3,4-tetrahydro-6-nitro-2,3-dioxobenzo[f]quinoxaline-7-sulfonamide (NBQX) were a gift from Novo Nordisk (MålØv, Denmark). All other drugs were purchased from Sigma (St. Louis, MO).

Preparation of dihydro-MEQ. For loading hippocampal slices, MEQ was reduced to its cell-permeable derivative, 6-methoxy- $N$-ethyl-1,2dihydroquinoline (dihydro-MEQ) as described previously by our laboratory (Inglefield and Schwartz-Bloom, 1997). Briefly, reduction was performed by gradual addition of sodium borohydride $\left(12 \%\right.$ in $\left.\mathrm{H}_{2} \mathrm{O}, 32 \mu \mathrm{M}\right)$ to an aqueous solution of MEQ $(16 \mu \mathrm{M})$ under nitrogen for $30 \mathrm{~min}$. Formation of the dihydro derivative was accompanied by the appearance of a reddish-yellow oil that was extracted twice with ethyl acetate $(0.5$ $\mathrm{ml})$. Organic extracts were combined and dried with anhydrous $\mathrm{MgSO}_{4}$, and the ethyl acetate was evaporated under $\mathrm{N}_{2}$ in a glass microvial. Reduced dye was stored at $-80^{\circ} \mathrm{C}$ under $\mathrm{N}_{2}$ and used within $2-3 \mathrm{~d}$ for optimal loading of brain slices.

Hippocampal slice preparation and bath loading of dihydro-MEQ. Transverse hippocampal slices $(300 \mu \mathrm{m})$ were prepared from 12- to 19-d-old Sprague Dawley rats (Charles River Laboratories, Wilmington, MA) using a vibratome in ice-cold oxygenated $\left(95 \% \mathrm{O}_{2}-5 \% \mathrm{CO}_{2}\right.$ mixture $)$ physiological Ringer's buffer. Composition of the Ringer's buffer consisted of (in mM): $119 \mathrm{NaCl}, 2.5 \mathrm{KCl}, 1.0 \mathrm{NaH}_{2} \mathrm{PO}_{4}, 1.3 \mathrm{MgCl}_{2}, 2.5$ $\mathrm{CaCl}_{2}, 26 \mathrm{NaHCO}_{3}$, and 11 glucose, $\mathrm{pH}$ 7.4. The osmolality of this buffer was $285-290 \mathrm{mOsm} / 1$. For low $\mathrm{Ca}^{2+}$ or $\mathrm{Na}^{+}$-containing buffers, appropriate iso-osmotic ion equivalents were added to account for osmolality and $\mathrm{pH}$ changes caused by removal of ions. Slices were transferred to a nylon net submerged in oxygenated Ringer's buffer (room temperature) and allowed to equilibrate for at least $0.5-1 \mathrm{hr}$ before dye loading. Bath loading of slices with resuspended dihydro-MEQ (final concentration of $\sim 400 \mu \mathrm{M}$ ) was carried out at room temperature for $30 \mathrm{~min}$ in Ringer's buffer. The slices were washed once in fresh oxygenated Ringer's to remove extracellular dye before transfer to the imaging chamber. Intracellularly trapped MEQ has high $\mathrm{Cl}^{-}$sensitivity, low toxicity, and a slow leakage rate (Biwersi and Verkman, 1991). Because the fluorescence of $\mathrm{MEQ}$ is quenched collisionally by $\mathrm{Cl}^{-}$, fluorescence intensity is inversely related to $\left[\mathrm{Cl}^{-}\right] \mathrm{i}$.

UV laser scanning confocal microscopy. The use of UV laser scanning confocal microscopy to measure $\mathrm{Cl}^{-}$-sensitive changes in MEQ fluorescence in hippocampal slices has been described previously by our laboratory (Inglefield and Schwartz-Bloom, 1997). After loading with MEQ, slices were submerged in a chamber that was superfused with oxygenated Ringer's buffer (flow rate of $\sim 1.5 \mathrm{ml} / \mathrm{min}$ ) at room temperature. For all experiments, slices were allowed to equilibrate in the chamber for at least $10-15 \mathrm{~min}$ before the baseline recording period. The imaging chamber was positioned on the stage of an upright Nikon (Tokyo, Japan) Optiphot microscope. The laser scanning confocal microscope (Noran Odyssey; Noran Instruments, Middleton, WI) was equipped with an argon ion UV laser (50 mW output; Enterprise 653; Coherent-AMT, Kitchener, Ontario, Canada) and a digital imaging system using Image-1 software (Universal Imaging Corporation, West Chester, PA) for image and data acquisition. MEQ-loaded neurons were imaged by excitation with the $364 \mathrm{~nm}$ line of the UV laser (attenuated to $18 \%$ intensity using the acousto-optical modulator of this system). Fluorescent light was transmitted through a UV water-immersible objective $(40 \times$ NA; Olympus Optical, Tokyo, Japan). Emission (Em ${ }_{\max }$ of $440 \mathrm{~nm}$ ) was imaged using a $400 \mathrm{~nm}$ barrier filter. Photomultipliers detected the fluorescent signal through a confocal slit at $1 \times$ electronic zoom (unless otherwise noted). The video frame rates (32 images per second) of the Noran Odyssey confocal microscope allowed rapid full-image $(512 \times 480$ pixels $)$ acquisition. To minimize photobleaching of the dye, repeated long-term illumination by the UV laser was limited. Previously, we have characterized the kinetics of photobleaching of MEQ to have a half-life $\left(t_{1 / 2}\right)$ of 173.8 sec (Inglefield and Schwartz-Bloom, 1997). Optical recordings totaling 1 $\mathrm{sec}$ of laser illumination were made every $2-5 \mathrm{~min}$, ensuring total laser illumination of no more than $15 \mathrm{sec} /$ slice. Images were 8-bit (256 intensity levels) and were recorded to a Panasonic (Secaucus, NJ) optical memory disk recorder (model LQ-3031) for off-line analysis. Before switching to $\mathrm{H}_{2} \mathrm{O}_{2}$ or drug-containing buffer, a minimum of $5 \mathrm{~min}$ of baseline was recorded to allow determination of the stable fluorescence of the cells. When inhibitors were used, they were superfused during the equilibration period (10-15 $\mathrm{min})$ to ensure penetration within the slice.

Calibration of MEQ fluorescence sensitivity. Because MEQ is not a ratioable dye, absolute $\left[\mathrm{Cl}^{-}\right]$i concentrations were not measured. However, changes in MEQ fluorescence can be calibrated to estimate changes in intracellular $\left[\mathrm{Cl}^{-}\right]$using the Stern-Volmer relationship, $F_{0} / F_{\mathrm{Cl}}=1+$ $K q[\mathrm{Cl}]$, where $F_{0}$ is the total quenchable signal, $F_{\mathrm{Cl}}$ is the fluorescence in the presence of a given $\mathrm{Cl}^{-}$concentration, and $K q$ is the Stern-Volmer quench constant (in $\mathrm{M}^{-1}$ ) (Verkman, 1990). Previously, we have calibrated changes in MEQ fluorescence with intracellular $\mathrm{Cl}^{-}$under different experimental conditions (Inglefield and Schwartz-Bloom, 1997, 1998). For the imaging conditions described here, we determined the Stern-Volmer constant $(K q)$ to be $16 \pm 1 \mathrm{M}^{-1}$. The $\mathrm{Kq}^{-1}$ equals $61 \mathrm{~mm}$, the $\mathrm{Cl}^{-}$concentration to quench MEQ fluorescence by $50 \%$.

Propidium iodide fluorescence imaging. In certain experiments, MEQloaded slices were superfused in the imaging chamber with propidium iodide (PI) $(2 \mu \mathrm{g} / \mathrm{ml})$ for $5 \mathrm{~min}$ before imaging. Propridium iodide was maintained in the buffer throughout the experiment to prevent washout from the extracellular space. Healthy cells are impermeable to PI. However, it enters neurons with damaged plasma membranes and fluoresces upon binding to nucleic acids. Detection of PI-positive neurons (indicating damaged plasma membranes) was achieved with a $488 \mathrm{~nm}$ excitation line and a $550 \mathrm{~nm}$ barrier filter.

Carboxy-dichlorofluorescein fluorescence imaging. To monitor the accumulation of intracellular peroxides, separate slices (non-MEQ-loaded) were loaded with the nonfluorescent dye $\mathrm{c}-\mathrm{H}_{2}$ DCFDA $(10 \mu \mathrm{M})$ for 30 min at $30^{\circ} \mathrm{C}$. This dye is freely permeable to cells, and it becomes trapped inside after hydrolysis to carboxy-dichlorodihydrofluorescein. Upon oxidation by intracellular oxidants, primarily peroxides, it forms fluorescent carboxy-dichlorofluorescein (c-DCF) (LeBel et al., 1992). Increases in c-DCF fluorescence dependent on intracellular oxidant status were measured using the $488 \mathrm{~nm}$ excitation line and a $515 \mathrm{~nm}$ barrier filter. Laser illumination was limited to $1 \mathrm{sec}$ exposures at $5 \mathrm{~min}$ intervals for $15 \mathrm{~min}$, and images were acquired using 16 frame averaging to minimize photo-oxidation of this dye. Control slices were exposed to $\mathrm{H}_{2} \mathrm{O}_{2}$-free Ringer's under identical conditions.

Data analysis. Only those cells that had $<10 \%$ change in MEQ fluorescence during the initial baseline recording period and an initial fluorescence intensity between 90-200 optical density units were used for data analysis. Fluorescence intensity (optical density arbitrary units) was measured over a central area of 5-10 morphologically distinct somata per slice within the imaged field. Within each frame, the average fluorescence intensity, $F$, for either MEQ or c-DCF fluorescence was calculated and recorded. The percent change in fluorescence from baseline for each cell $(\Delta F)$ was calculated by the equation $\Delta F=\left(F_{\mathrm{b}}-F / F_{\mathrm{b}}\right) \times 100$, where $F_{\mathrm{b}}$ was basal fluorescence defined by the three frames preceding the experimental recordings. Thus, each cell served as its own control. There was a gradual rundown (baseline drift) of MEQ fluorescence $(9.9 \pm 2 \%$ over $20 \mathrm{~min}$ ) in control slices primarily because of slow leakage of the dye. Thus, changes in MEQ fluorescence induced by $\mathrm{H}_{2} \mathrm{O}_{2}$ were always compared with the fluorescence in slices not exposed to $\mathrm{H}_{2} \mathrm{O}_{2}$ under similar conditions (controls). Typically, we obtained data from three to four stable cells per slice, from at least two slices per experiment, repeated at least three times.

Measurement of amino acid overflow. To quantify the amounts of GABA and glutamate released from the hippocampal slices, $100 \mu \mathrm{l}$ of the superfusate was collected from slices exposed to $\mathrm{H}_{2} \mathrm{O}_{2}$ for 2 and $10 \mathrm{~min}$. Superfusates were sampled from control slices at the same time points. Samples were stored at $-20^{\circ} \mathrm{C}$ until analysis. Neurotransmitter amino acids in the superfusates were derivitized with $o$-phthalaldehyde and assayed by HPLC on a C18 reversed-phase column $(4.6 \times 80 \mathrm{~mm}$; particle size, $3 \mu \mathrm{m}$; Zorbax; Hewlett-Packard Co., Newport, DE) using $700 \mathrm{~nm}$ cysteic acid as the internal standard (Lindroth and Mopper, 1979; Peterson et al., 1995). The limit of sensitivity was $\sim 50 \mathrm{fmol}$. 


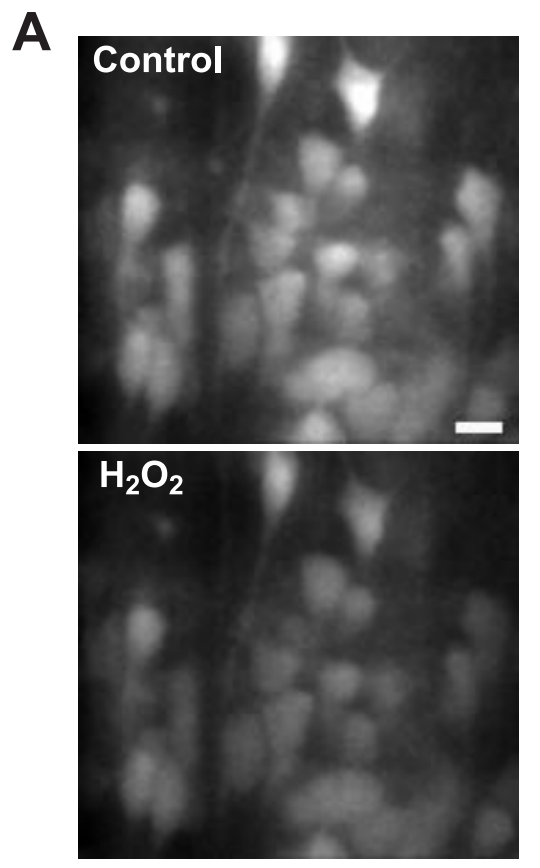

B

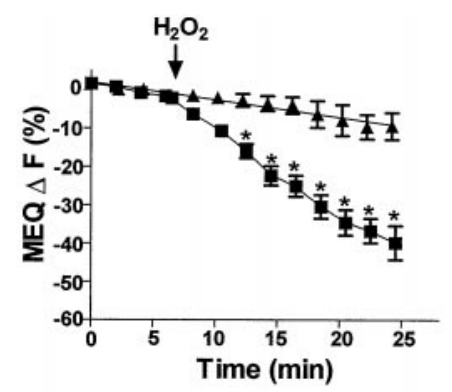

Figure 1. Effect of $\mathrm{H}_{2} \mathrm{O}_{2}$ on intracellular MEQ fluorescence in area CA1 pyramidal cells. $A$, Video confocal images of MEQ fluorescence before (Control) and 10 min after $\mathrm{H}_{2} \mathrm{O}_{2}(300 \mu \mathrm{M})$. The decreased fluorescence in the bottom indicates an increase in $\left[\mathrm{Cl}^{-}\right]$i. Scale bar, $20 \mu \mathrm{m}$. B, Time course for the $\mathrm{H}_{2} \mathrm{O}_{2}$-induced changes in MEQ fluorescence within individual pyramidal cells. After baseline recordings, hippocampal slices were

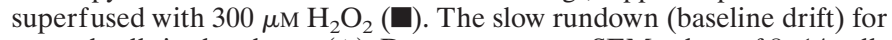
control cells is also shown $(\mathbf{\Delta})$. Data are mean \pm SEM values of $8-14$ cells for control and $\mathrm{H}_{2} \mathrm{O}_{2}$ (4 slices per condition) from three separate experiments. ${ }^{*} p<0.05$ versus baseline fluorescence; repeated-measures ANOVA followed by Tukey's post hoc analysis.

\section{RESULTS}

\section{$\mathrm{H}_{2} \mathrm{O}_{2}$ - induced changes in intracellular $\mathrm{Cl}^{-}$}

Freshly prepared hippocampal slices loaded with MEQ exhibited numerous fluorescent neurons with a uniform dye distribution in area CA1 stratum pyramidale (Fig. $1 A$ ). Dendrites of several neurons were clearly visible depending on the optical plane of focus. In hippocampal slices exposed to $\mathrm{H}_{2} \mathrm{O}_{2}(300 \mu \mathrm{M} ; 0.001 \%)$, MEQ fluorescence decreased gradually in the cell soma of area CA1 stratum pyramidale (Fig. 1), indicating an accumulation of intracellular $\mathrm{Cl}^{-}$. When $\mathrm{H}_{2} \mathrm{O}_{2}$ was removed from the superfusion buffer after $10 \mathrm{~min}$, no additional decrease in MEQ fluorescence was observed over the next $25 \mathrm{~min}$ (data not shown). Ten minutes after exposure to $\mathrm{H}_{2} \mathrm{O}_{2}$, MEQ fluorescence decreased by $32 \pm$ $2 \%$ compared with a $9.9 \pm 0.8 \%$ decrease in control slices over the same time period (also see Fig. 5). According to the SternVolmer relationship (see Materials and Methods), the decrease in

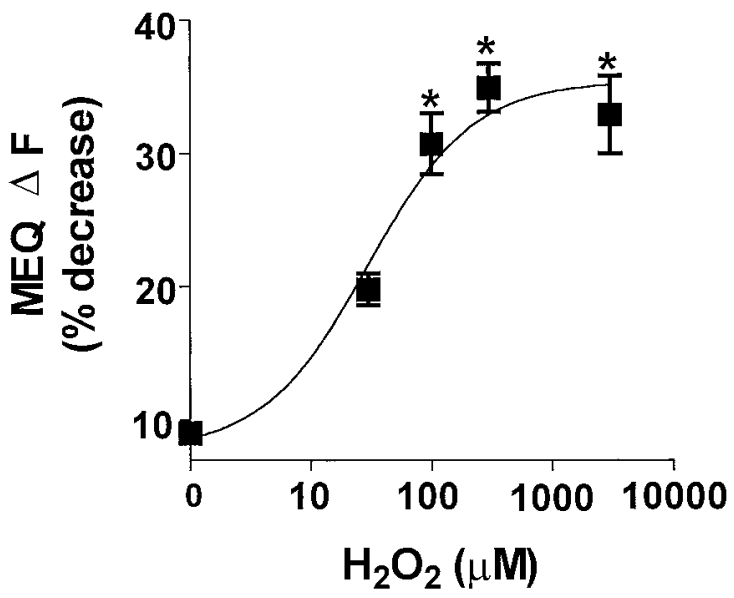

Figure 2. Concentration-dependent decrease in MEQ fluorescence by $\mathrm{H}_{2} \mathrm{O}_{2}$. MEQ-loaded slices were exposed to increasing concentrations of $\mathrm{H}_{2} \mathrm{O}_{2}$. The change in MEQ fluorescence $(\Delta F)$ was calculated as percent of baseline fluorescence for individual cells after $10 \mathrm{~min}$ of $\mathrm{H}_{2} \mathrm{O}_{2}$. Data are from $6-25$ cells from at least three slices per condition. ${ }^{*} p<0.05$ versus control; ANOVA and Tukey's post hoc analysis.

MEQ fluorescence produced by 10 min $\mathrm{H}_{2} \mathrm{O}_{2}$ exposure (corrected for baseline drift) corresponds to an increase in intracellular $\mathrm{Cl}^{-}$of $\sim 27 \mathrm{mM}$ (resting $\left[\mathrm{Cl}^{-}\right]$i typically ranges between 4 and 9 $\mathrm{mM}$ for neurons). The change in MEQ fluorescence produced by $\mathrm{H}_{2} \mathrm{O}_{2}$ in pyramidal neurons was concentration-dependent (Fig. 2). No change in MEQ fluorescence was observed below a concentration of $30 \mu \mathrm{M} \mathrm{H}_{2} \mathrm{O}_{2}$ compared with control cells. However, a significant reduction in MEQ fluorescence was observed at concentrations $\geq 100 \mu \mathrm{M}$ of $\mathrm{H}_{2} \mathrm{O}_{2}$, and a maximal response was observed at $300 \mu \mathrm{M} \mathrm{H}_{2} \mathrm{O}_{2}$. Applying higher concentrations in the millimolar range produced no further decrease in MEQ fluorescence. We did not test concentrations above $10 \mathrm{~mm}$ because these concentrations have been reported to produce primary cytoplasmic and plasma membrane damage and rapid necrosis (Gardner et al., 1997). Unless noted otherwise, all experiments were performed with $300 \mu \mathrm{M} \mathrm{H}_{2} \mathrm{O}_{2}$.

In contrast to pyramidal neurons, interneurons in area CA1 stratum radiatum were resistant to $\mathrm{H}_{2} \mathrm{O}_{2}$-induced changes in MEQ fluorescence (Fig. $3 A$ ). Ten minutes after $\mathrm{H}_{2} \mathrm{O}_{2}$ exposure, there was no decrease in MEQ fluorescence compared with controls (Fig. 3B). These findings are consistent with the reported differences in vulnerability of area CA1 interneurons versus pyramidal neurons after ischemic insults in vivo (Crain et al., 1988; Inglefield et al., 1997).

\section{C-DCF fluorescence in neurons after $\mathrm{H}_{2} \mathrm{O}_{2}$}

To verify that $10 \mathrm{~min}$ superfusion lead to adequate penetration of $\mathrm{H}_{2} \mathrm{O}_{2}$ within neurons, we assessed intracellular accumulation of $\mathrm{H}_{2} \mathrm{O}_{2}$ and other ROS in neuronal cell soma of CA1 pyramidal neurons using the oxidation-sensitive dye c-DCF. This dye has been used as a probe for evaluating $\mathrm{H}_{2} \mathrm{O}_{2}$ and other ROS, and therefore, it is an indicator of oxidative stress in biological systems (LeBel et al., 1992; Crow, 1997). There was a significant increase $(53 \pm 6.6 \%)$ in c-DCF fluorescence in area CA1 pyramidal neurons exposed to $300 \mu \mathrm{M} \mathrm{H}_{2} \mathrm{O}_{2}$ for $10 \mathrm{~min}$ (Fig. 4). In addition, intense c-DCF fluorescence, which was punctate in distribution, was observed in the neuropil area in most slices. The punctate staining in the neuropil most likely reflected ROS accumulation in both terminals and dendrites, and it precluded observation of individual c-DCF-loaded interneurons. Control slices 

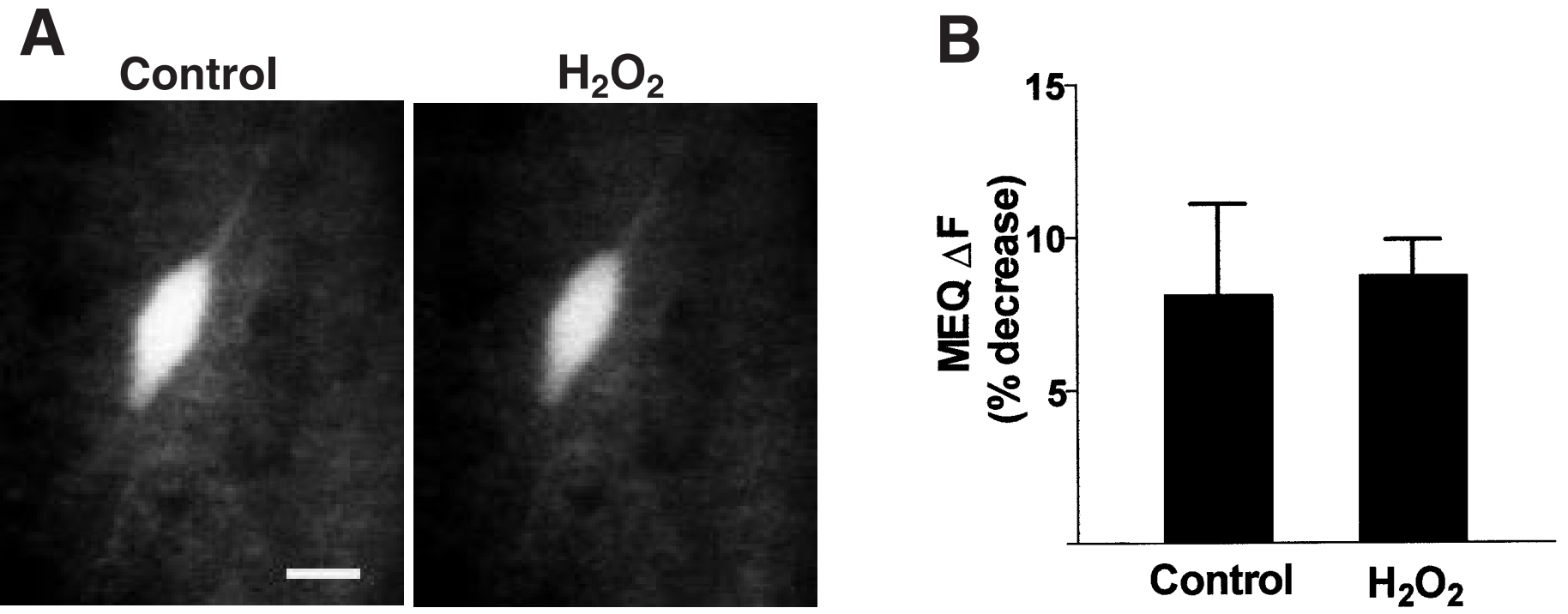

Figure 3. Effect of $\mathrm{H}_{2} \mathrm{O}_{2}$ on intracellular MEQ fluorescence in interneurons located in area CA1 stratum radiatum. $A$, Video confocal images of MEQ fluorescence in an area CA1 interneuron before and 10 min after $300 \mu \mathrm{M} \mathrm{H}_{2} \mathrm{O}_{2}$ superfusion. Scale bar, $20 \mu \mathrm{m} . B, \mathrm{H}_{2} \mathrm{O}_{2}(10 \mathrm{~min}$ superfusion) causes no significant change in MEQ fluorescence in interneurons. Control bar represents the baseline drift (over 10 min) of MEQ fluorescence in cells exposed to Ringer's buffer without $\mathrm{H}_{2} \mathrm{O}_{2}$, under identical experimental conditions. Data are mean $\pm \mathrm{SEM}$ of four to nine cells from four to six slices.

loaded with c-DCF and exposed to similar periods of laser illumination elicited minimal changes in c-DCF fluorescence during the experimental period $(6.3 \pm 2.2 \%)$, indicating negligible laserinduced auto-oxidation and photoconversion of the dye (Fig. 4B). The increase in c-DCF fluorescence was more rapid in some neurons, which showed significant increases in c-DCF fluorescence by 5 min of $\mathrm{H}_{2} \mathrm{O}_{2}$ superfusion (data not shown). The variability could be related to the intracellular $\mathrm{H}_{2} \mathrm{O}_{2}$ antioxidant status of individual neurons.

\section{$\mathrm{H}_{2} \mathrm{O}_{2}$ effects are mediated via free radicals}

Normally, $\mathrm{H}_{2} \mathrm{O}_{2}$ is metabolized by glutathione peroxidase or catalase to water and a disulfide, or water and $\mathrm{O}_{2}$, respectively. If the antioxidant capacity is exceeded, $\mathrm{H}_{2} \mathrm{O}_{2}$, along with free $\mathrm{Fe}^{2+}$, promotes the production of hydroxyl radicals $(\mathrm{OH} \cdot)$ via the Fenton reaction (Haber and Weiss, 1934), which peroxidizes lipids and proteins. To determine whether free radical generation was involved in the effect of $\mathrm{H}_{2} \mathrm{O}_{2}$ on MEQ fluorescence, slices were superfused with the iron chelator deferoxamine mesylate (100 $\mu \mathrm{M})$. Deferoxamine completely prevented the $\mathrm{H}_{2} \mathrm{O}_{2}$-induced decrease in MEQ fluorescence (Fig. 5). In addition, superfusion of slices with Trolox $(50 \mu \mathrm{M})$, a water-soluble form of $\alpha$-tocopherol (vitamin E), prevented the ability of $\mathrm{H}_{2} \mathrm{O}_{2}$ to decrease MEQ fluorescence (Fig. 5). Thus, the $\mathrm{H}_{2} \mathrm{O}_{2}$-induced effects on $\left[\mathrm{Cl}^{-}\right] \mathrm{i}$ were probably a result of free radical generation, most likely hydroxyl radicals rather than $\mathrm{H}_{2} \mathrm{O}_{2}$ itself.

\section{Propidium iodide fluorescence in MEQ-loaded cells after $\mathrm{H}_{2} \mathrm{O}_{2}$}

Free radicals, primarily $\mathrm{OH}$, can lead to peroxidation of membrane phospholipids, resulting in a loss of membrane integrity and cell death (Mattson, 1998). To determine whether neurons exposed to $\mathrm{H}_{2} \mathrm{O}_{2}$ maintained plasma membrane integrity, the MEQ-loaded slices were also loaded with PI, which is excluded from living cells with intact plasma membranes. As the plasma membrane becomes permeable, PI enters; it is relatively nonfluorescent until it binds to nuclear chromatin. Control cells loaded with MEQ showed no PI fluorescence (Fig. 6 $A, B$ ). Furthermore, cells continued to exclude PI after superfusion with $\mathrm{H}_{2} \mathrm{O}_{2}$ for 10 min (Fig. 6D) and showed a significant reduction in MEQ fluorescence (Fig. $6 C$ ). Thus, the concentration of $\mathrm{H}_{2} \mathrm{O}_{2}$ used (300 $\mu \mathrm{M}$ ) does not appear to damage plasma membranes. At the end of the experiment, the slices were incubated in Ringer's buffer containing $70 \%$ methanol as a positive control to permeabilize the cell membranes. Two minutes after exposure to methanol, there was intense nuclear staining of cells by PI (Fig. 6E), accompanied by a loss of MEQ fluorescence caused by damaged cell membranes (data not shown).

\section{$\mathrm{H}_{2} \mathrm{O}_{2}$-induced changes in $\left[\mathrm{Cl}^{-}\right] \mathrm{i}$ are secondary to release of GABA and activation of excitatory amino acid receptors by glutamate}

Increases in intracellular $\mathrm{Cl}^{-}$in neurons may occur as a result of opening of ligand-gated $\mathrm{Cl}^{-}$channels, e.g., $\mathrm{GABA}_{\mathrm{A}}$ receptors, passive influx to accompany $\mathrm{Na}^{+}$, or an impairment of $\mathrm{Cl}^{-}$ extrusion mechanisms (Alvarez-Leefmans, 1990). We performed specific antagonist and ion replacement experiments to determine potential mechanism(s) for the $\mathrm{H}_{2} \mathrm{O}_{2}$-induced accumulation of $\left[\mathrm{Cl}^{-}\right]$i. Superfusion of the slices with the noncompetitive $\mathrm{GABA}_{\mathrm{A}}$ receptor antagonist picrotoxin $(100 \mu \mathrm{M})$ prevented the decrease in MEQ fluorescence of pyramidal cells produced by $\mathrm{H}_{2} \mathrm{O}_{2}$ (Table 1), suggesting that $\mathrm{Cl}^{-}$influx was probably secondary to GABA release. Tetrodotoxin $(2 \mu \mathrm{M})$ had no affect on the $\mathrm{H}_{2} \mathrm{O}_{2}$-induced change in MEQ fluorescence (Table 1), indicating a lack of involvement of voltage-dependent $\mathrm{Na}^{+}$channels in the elevation of $\left[\mathrm{Cl}^{-}\right] \mathrm{i}$ by $\mathrm{H}_{2} \mathrm{O}_{2}$. To assess whether GABA was released by $\mathrm{H}_{2} \mathrm{O}_{2}$, we measured GABA levels in the superfusates after exposure of hippocampal slices to $\mathrm{H}_{2} \mathrm{O}_{2}$ under identical conditions used for imaging (Fig. 7). Within 2 min of $\mathrm{H}_{2} \mathrm{O}_{2}$ superfusion, there was a significant increase in the levels of GABA in the superfusate. In addition, glutamate levels increased by 2 min of $\mathrm{H}_{2} \mathrm{O}_{2}$ superfusion, but the increase was variable and did not reach statistical significance. To determine whether the $\mathrm{H}_{2} \mathrm{O}_{2}$-induced increase in $\left[\mathrm{Cl}^{-}\right] \mathrm{i}$ involved the activation of excitatory amino acid (EAA) receptors, slices were incubated with D-AP-5 $(50 \mu \mathrm{M})$ or NBQX $(5 \mu \mathrm{M})$, selective antagonists of NMDA and AMPA receptors, respectively. Both compounds 
A
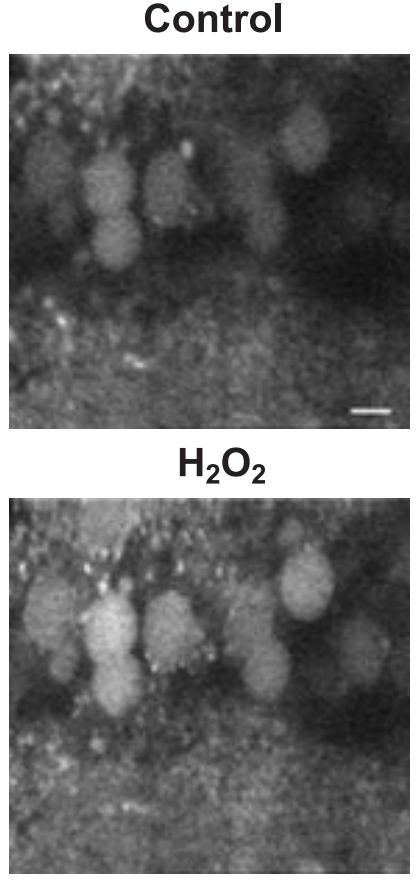

B

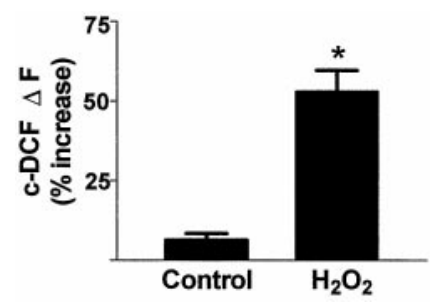

Figure 4. Increased c-DCF fluorescence in cells after 10 min $\mathrm{H}_{2} \mathrm{O}_{2}$, indicating elevation of ROS. $A$, Confocal video images of c-DCF fluorescence in area CA1 pyramidal cell soma before (Control) and after $\mathrm{H}_{2} \mathrm{O}_{2}$ superfusion. Scale bar, $20 \mu \mathrm{m}$. $B$, Changes in c-DCF fluorescence after 10 min $\mathrm{H}_{2} \mathrm{O}_{2}$. Control bar represents the baseline drift of c-DCF fluorescence in cells not exposed to $\mathrm{H}_{2} \mathrm{O}_{2}$ under identical experimental conditions. Data are mean \pm SEM values of $12-22$ cells from three to five slices. ${ }^{*} p<$ 0.05 versus control; Student's $t$ test.

significantly attenuated the effect of $\mathrm{H}_{2} \mathrm{O}_{2}$ on MEQ fluorescence (Table 1), indicating that activation of EAA receptors by glutamate was also a component in the cascade of $\mathrm{H}_{2} \mathrm{O}_{2}$-mediated effects on intracellular $\mathrm{Cl}^{-}$.

$\mathrm{Ca}^{2+}$ ions mediate the $\mathrm{H}_{2} \mathrm{O}_{2}$-induced elevation in $\left[\mathrm{Cl}^{-}\right] \mathrm{i}$ Oxidative species can cause the release of GABA via a $\mathrm{Ca}^{2+}$ dependent exocytotic process (Rego et al., 1996) and via a $\mathrm{Ca}^{2+}$ independent, $\mathrm{Na}^{+}$-dependent GABA carrier-mediated efflux (Oliveira et al., 1994). To investigate whether the $\mathrm{H}_{2} \mathrm{O}_{2}$-induced increase in intracellular $\mathrm{Cl}^{-}$required the presence of $\mathrm{Ca}^{2+}$, we superfused slices in a $\mathrm{Ca}^{2+}$-deficient Ringer's buffer containing 1 mM EGTA, before the addition of $\mathrm{H}_{2} \mathrm{O}_{2}$. The removal of extracellular $\mathrm{Ca}^{2}+$ markedly prevented the decrease in MEQ fluorescence by $\mathrm{H}_{2} \mathrm{O}_{2}$ (Fig. 8). Thus, the ability of $\mathrm{H}_{2} \mathrm{O}_{2}$ to elevate $\left[\mathrm{Cl}^{-}\right] \mathrm{i}$ appears to be dependent on the influx of $\mathrm{Ca}^{2+}$. To determine whether GABA carrier-mediated efflux (i.e., carrier reversal) contributed to the $\mathrm{H}_{2} \mathrm{O}_{2}$-induced increase in intracellular $\mathrm{Cl}^{-}$, we substituted $\mathrm{Na}^{+}$(from $\mathrm{NaCl}$ ) in the superfusion buffer with an equimolar concentration of choline chloride. The

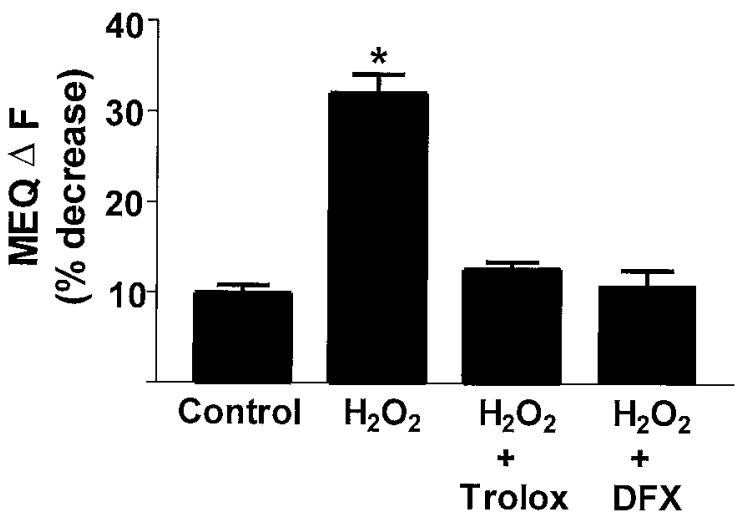

Figure 5. Effect of Trolox $(50 \mu \mathrm{M})$ and deferoxamine mesylate (DFX; 100 $\mu \mathrm{M})$ on $\mathrm{H}_{2} \mathrm{O}_{2}$-induced decreases in MEQ fluorescence. Hippocampal slices were superfused with $300 \mu \mathrm{M} \mathrm{H} \mathrm{H}_{2} \mathrm{O}_{2}$ for $10 \mathrm{~min}$. The compounds were added $15 \mathrm{~min}$ before the addition of $\mathrm{H}_{2} \mathrm{O}_{2}$. Data are mean \pm SEM values of 10-24 cells from at least three slices per condition. ${ }^{*} p<0.05$ versus control; ANOVA followed by Tukey's test.

removal of $\mathrm{Na}^{+}$had no effect on the ability of $\mathrm{H}_{2} \mathrm{O}_{2}$ to decrease MEQ fluorescence (Fig. 8).

\section{$\mathrm{H}_{2} \mathrm{O}_{2}$ decreases $\mathrm{GABA}$. responses}

To determine whether the $\mathrm{H}_{2} \mathrm{O}_{2}$-induced elevation in intracellular $\mathrm{Cl}^{-}$could limit $\mathrm{GABA}_{\mathrm{A}}$ responses in the hippocampal slice, slices were superfused with $\mathrm{H}_{2} \mathrm{O}_{2}$ for $10 \mathrm{~min}$, and the $\mathrm{H}_{2} \mathrm{O}_{2}$ was removed. The slices were superfused subsequently with the $\mathrm{GABA}_{\mathrm{A}}$ agonist muscimol $(50 \mu \mathrm{M})$ for $10 \mathrm{~min}$. At this time, the ability of muscimol to decrease MEQ fluorescence was significantly attenuated (by $25 \% ; p<0.05$ ) compared with control slices not exposed to $\mathrm{H}_{2} \mathrm{O}_{2}$ (Fig. 9).

\section{DISCUSSION}

In the present study, we used the $\mathrm{Cl}^{-}$-sensitive dye MEQ and laser scanning confocal microscopy to assess alterations in intraneuronal $\mathrm{Cl}^{-}$in the hippocampal slice after a mild oxidative insult induced by $\mathrm{H}_{2} \mathrm{O}_{2}$. The use of the brain slice preparation, which maintains a relatively intact circuitry, allowed us to image both pyramidal neurons and interneurons under identical conditions. A brief exposure of slices to $\mathrm{H}_{2} \mathrm{O}_{2}$ caused a significant increase in $\left[\mathrm{Cl}^{-}\right] \mathrm{i}$ in $\mathrm{CA} 1$ pyramidal cell soma. A comparison of the effects of $\mathrm{H}_{2} \mathrm{O}_{2}$ on MEQ and c-DCF fluorescence indicated that the increase in $\left[\mathrm{Cl}^{-}\right] \mathrm{i}$ occurred simultaneously with the accumulation of $\mathrm{H}_{2} \mathrm{O}_{2}$ and related ROS inside the cell soma. Normally, ambient levels of $\mathrm{H}_{2} \mathrm{O}_{2}$ in neurons are low because of its efficient destruction by glutathione peroxidase (Halliwell and Gutteridge, 1989). However, micromolar concentrations $(\sim 100$ $\mu \mathrm{M})$ of $\mathrm{H}_{2} \mathrm{O}_{2}$ are found in brain after ischemia-reperfusion injury as measured by microdialysis (Hyslop et al., 1995). These micromolar concentrations can also be reached in aged brain tissue (Sohal et al., 1994; Auerbach and Segal, 1997), possibly because of an overproduction and/or reduced metabolism of $\mathrm{H}_{2} \mathrm{O}_{2}$.

In contrast to the acute sensitivity of pyramidal neurons to $\mathrm{H}_{2} \mathrm{O}_{2}$, interneurons located in area CA1 stratum radiatum did not demonstrate an increase in $\left[\mathrm{Cl}^{-}\right] \mathrm{i}$ in response to $\mathrm{H}_{2} \mathrm{O}_{2}$. Interestingly, differences in vulnerability of neuronal types to neurodegenerative processes have been observed in cerebral ischemia and in Huntington's disease (Crain et al., 1988; Inglefield et al., 1997; Calabresi et al., 1998). GABAergic interneurons in the hippocampus have been shown to survive long-term after an episode of cerebral ischemia, although they do suffer considerable damage 

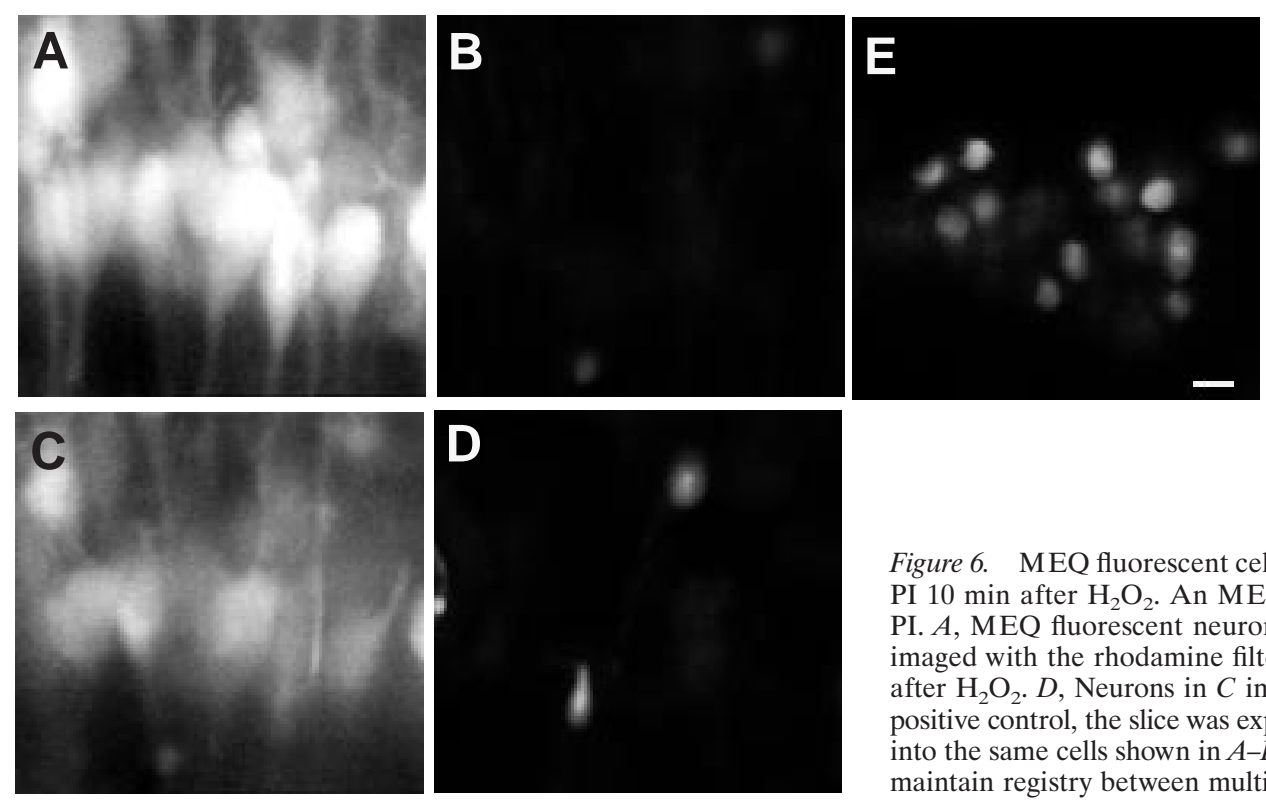

Figure 6. MEQ fluorescent cells within area CA1 pyramidal cell layer exclude PI 10 min after $\mathrm{H}_{2} \mathrm{O}_{2}$. An MEQ-loaded slice was constantly superfused with PI. $A$, MEQ fluorescent neurons in area CA1 before $\mathrm{H}_{2} \mathrm{O}_{2} . B$, Neurons in $A$ imaged with the rhodamine filter for PI. $C$, MEQ fluorescent neurons $10 \mathrm{~min}$ after $\mathrm{H}_{2} \mathrm{O}_{2}$. D, Neurons in $C$ imaged with the rhodamine filter for PI. $E$, As a positive control, the slice was exposed to methanol for 2 min to allow entry of PI into the same cells shown in $A-D$. All images were at a $1.7 \times$ electronic zoom to maintain registry between multiple laser lines. Scale bar, $20 \mu \mathrm{m}$.

(Nitsch et al., 1989; Inglefield et al., 1997). The exact reason(s) for the differing responses to $\mathrm{H}_{2} \mathrm{O}_{2}$ between these two cell types is not clear at present. However, some possible explanations may include the following: (1) different levels of intracellular antioxidants, (2) heterogeneity in $\mathrm{GABA}_{\mathrm{A}}$-mediated $\mathrm{Cl}^{-}$currents, (3) different efficiencies of $\mathrm{Cl}^{-}$extrusion mechanisms, and (4) the neuronal circuitry. Interestingly, different levels of superoxide dismutase (SOD1 and SOD2 isoforms) have been reported in striatal cholinergic interneurons versus projection neurons, the latter being more susceptible to neurodegenerative processes (Yamada et al., 1995; Medina et al., 1996). Also, differential vulnerability of CA1 and CA3 subfields to superoxide and hydroxyl radicals has been reported in hippocampal slices (Wilde et al., 1997); this difference in vulnerability was attributed primarily to different levels of antioxidant enzymes and iron binding proteins between the two cell populations. Differences between pyramidal neurons and interneurons may also exist with respect to $\mathrm{Cl}^{-}$

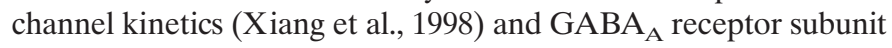
composition (Sperk et al., 1997). In addition, differential responses to oxidative stress have been reported in thalamic and cortical neurons based on neuronal circuitary in which loss or preservation of certain pathways modified electrophysiological responses to $\mathrm{H}_{2} \mathrm{O}_{2}$ (Frantseva et al., 1998). Future studies are required to fully

\begin{tabular}{|c|c|}
\hline Treatment & MEQ $\Delta F(\%$ decrease $)$ \\
\hline Control & $9.9 \pm 0.8$ \\
\hline $\mathrm{H}_{2} \mathrm{O}_{2}(300 \mu \mathrm{M})$ & $32.0 \pm 2.0^{*}$ \\
\hline $\mathrm{H}_{2} \mathrm{O}_{2}+\operatorname{PTX}(100 \mu \mathrm{M})$ & $10.0 \pm 2.3$ \\
\hline $\mathrm{H}_{2} \mathrm{O}_{2}+\mathrm{AP}-5(50 \mu \mathrm{M})$ & $15.1 \pm 1.0$ \\
\hline $\mathrm{H}_{2} \mathrm{O}_{2}+\mathrm{NBQX}(5 \mu \mathrm{M})$ & $12.0 \pm 1.6$ \\
\hline $\mathrm{H}_{2} \mathrm{O}_{2}+\operatorname{TTX}(2 \mu \mathrm{M})$ & $32.5 \pm 2.0^{*}$ \\
\hline
\end{tabular}

Slices were superfused with $\mathrm{H}_{2} \mathrm{O}_{2}$ for $10 \mathrm{~min}$. Compounds were added 15 min before the addition of $\mathrm{H}_{2} \mathrm{O}_{2}$. Controls represent drift in MEQ fluorescence in the absence of compounds and $\mathrm{H}_{2} \mathrm{O}_{2}$. Data are mean \pm SEM of 13-27 cells imaged from at least three individual slices in several experiments. * $p<0.05$ versus control; ANOVA and Tukey's post hoc test. understand the heterogeneity in responsiveness between hippocampal pyramidal neurons and interneurons to $\mathrm{H}_{2} \mathrm{O}_{2}$.

Alterations in $\left[\mathrm{Cl}^{-}\right] \mathrm{i}$ induced by $\mathrm{H}_{2} \mathrm{O}_{2}$ in pyramidal neurons were prevented in the presence of the iron chelator deferoxamine, suggesting that $\mathrm{H}_{2} \mathrm{O}_{2}$ effects were probably mediated by hydroxyl radicals rather than $\mathrm{H}_{2} \mathrm{O}_{2}$ itself. This is consistent with previous reports in which the effects of $\mathrm{H}_{2} \mathrm{O}_{2}$ on synaptic efficacy were dependent on the presence of free iron in hippocampal slices (Pellmar et al., 1989). The ability of the antioxidant Trolox to prevent the increase in $\left[\mathrm{Cl}^{-}\right] \mathrm{i}$ by $\mathrm{H}_{2} \mathrm{O}_{2}$ also supports a role of free radicals in the actions of $\mathrm{H}_{2} \mathrm{O}_{2}$.

How does $\mathrm{H}_{2} \mathrm{O}_{2}$ produce elevated intraneuronal $\mathrm{Cl}^{-}$in pyramidal cell soma? Significant reduction of $\mathrm{H}_{2} \mathrm{O}_{2}$ action by the GABA-gated $\mathrm{Cl}^{-}$channel antagonist picrotoxin indicates that accumulation of $\mathrm{Cl}^{-}$probably occurred as a result of its influx through the $\mathrm{GABA}_{\mathrm{A}}$ ionophore, secondary to elevation of extracellular GABA levels. To support this, we found increased levels

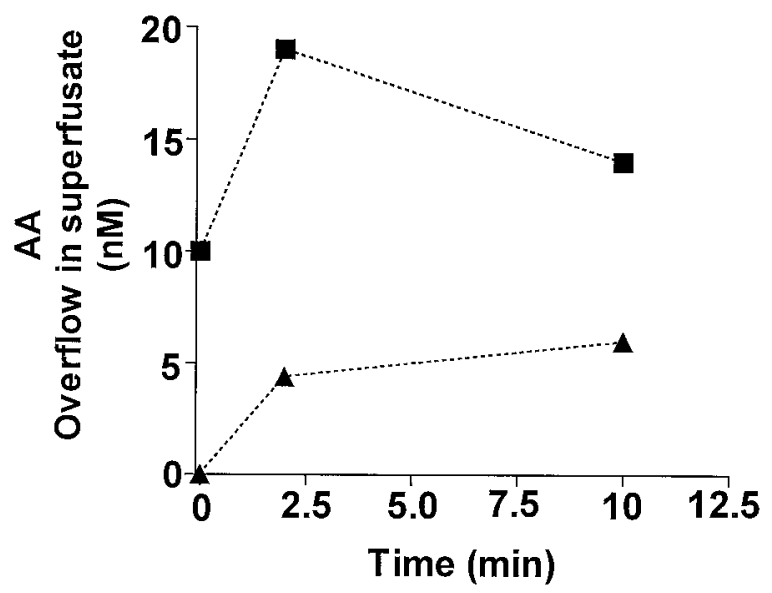

Figure 7. $\quad \mathrm{H}_{2} \mathrm{O}_{2}$ causes an increase of amino acids (AA), glutamate (-口-), and GABA (-A-) in the superfusate of hippocampal slices. Superfusates were collected at 0 (basal), 2, and 10 min after $300 \mu \mathrm{M} \mathrm{H}_{2} \mathrm{O}_{2}$. Data are from a single experiment and represent three separate experiments. Accumulation of GABA was significantly above basal $(p<0.05)$ at 2 and $10 \mathrm{~min}$ (repeated measures ANOVA, followed by paired Student's $t$ test). 


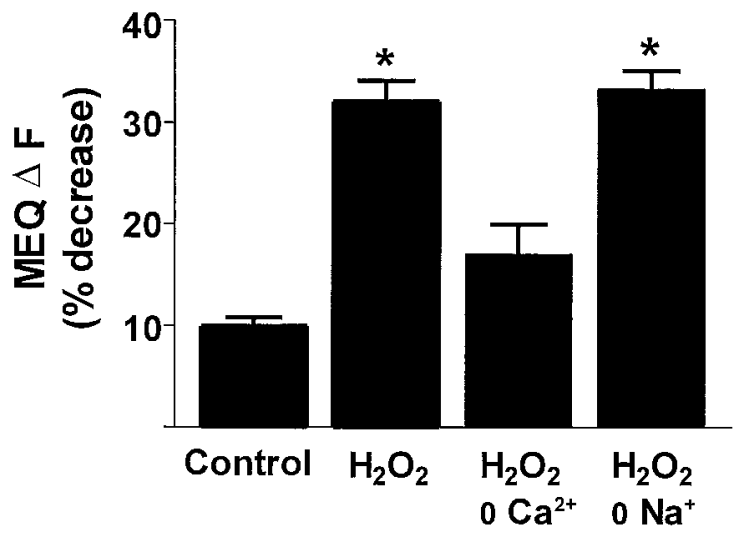

Figure 8. $\mathrm{H}_{2} \mathrm{O}_{2}$-induced $\mathrm{Cl}^{-}$influx is $\mathrm{Ca}^{2+}$-dependent and $\mathrm{Na}^{+}$independent. All ion-substituted buffers were iso-osmotic with the control Ringer's buffer. The $\mathrm{Ca}^{2+}$-deficient buffer also contained $1 \mathrm{~mm}$ EGTA. In the $\mathrm{Na}^{+}$-deficient buffer, choline chloride replaced $\mathrm{NaCl}$. Data are mean \pm SEM of 4-27 cells from at least three slices per condition. * $p<$ 0.05 versus control; ANOVA followed by Tukey's post hoc test.

of GABA in superfusates collected from $\mathrm{H}_{2} \mathrm{O}_{2}$-exposed slices. Our studies agree with previous studies in which oxygen free radicals increased basal release of GABA in hippocampal slices and in cultured chick retinal neurons (Rego et al., 1996; Saransaari and Oja, 1998). However, the mechanism(s) by which $\mathrm{H}_{2} \mathrm{O}_{2}$ alters intraneuronal $\mathrm{Cl}^{-}$is probably more complex because it must also account for the dependence of $\mathrm{H}_{2} \mathrm{O}_{2}$ action on glutamate receptor activation and on extracellular $\mathrm{Ca}^{2+}$. The ability of $\mathrm{H}_{2} \mathrm{O}_{2}$ and other ROS to cause glutamate accumulation has also been documented. For example, elevated levels of excitatory amino acids have been reported in hippocampal slices and neuronal cultures on exposure to free radicals because of enhanced release (Pellegrini-Giampietro et al., 1988; Satoh et al., 1998) or impaired uptake (Volterra et al., 1994; Berman and Hastings, 1997). Free radicals can enhance basal release of excitatory amino acids in the presence or absence of extracellular $\mathrm{Ca}^{2+}$ (Gilman et al., 1994; Rego et al., 1996). In addition, enhancement of excitatory neurotransmission was observed after $\mathrm{H}_{2} \mathrm{O}_{2}$ in thalamocortical neurons, along with attenuated inhibitory transmission (Frantseva et al., 1998).

There is significant evidence implicating impaired $\mathrm{Ca}^{2+}$ homeostasis after oxidative insults (Mattson, 1998). Recently, Li et al. (1998) have reported that $\mathrm{H}_{2} \mathrm{O}_{2}$ increased the $\mathrm{Ca}^{2+}$ channel currents in cloned neuronal voltage-dependent $\mathrm{Ca}^{2+}$ channels expressed in Xenopus oocytes. Elevated $\left[\mathrm{Ca}^{2+}\right] \mathrm{i}$ after $\mathrm{H}_{2} \mathrm{O}_{2}$ has also been reported in synaptosomes (Tretter and Adam-Vizi, 1996). Interestingly, elevated $\left[\mathrm{Ca}^{2+}\right] \mathrm{i}$ in response to glutamate receptor activation has been shown to increase levels of ROS (Dugan et al., 1995; Reynolds and Hastings, 1995; Bindokas et al., 1996).

A model that includes the hippocampal circuit may be proposed to account for the mechanism(s) by which $\mathrm{H}_{2} \mathrm{O}_{2}$ increases intracellular $\mathrm{Cl}^{-}$. After exposure to $\mathrm{H}_{2} \mathrm{O}_{2}$, glutamate could accumulate (via $\mathrm{Ca}^{2+}$-dependent release and/or impaired uptake) at synapses with GABA interneurons, thereby activating glutamate receptors and causing GABA release. This process appears to be TTXinsensitive. Because the effects of $\mathrm{H}_{2} \mathrm{O}_{2}$ were blocked by glutamate receptor antagonists, $\mathrm{Ca}^{2+}$-dependent release or impaired uptake of GABA at interneuron terminals appear to be insignificant. Thus, glutamate terminals may be more sensitive to $\mathrm{H}_{2} \mathrm{O}_{2}$ than are GABA terminals. In addition to promoting $\mathrm{Cl}^{-}$influx, $\mathrm{H}_{2} \mathrm{O}_{2}$ may also affect $\mathrm{Cl}^{-}$extrusion mechanisms. Neurons contain ATP-

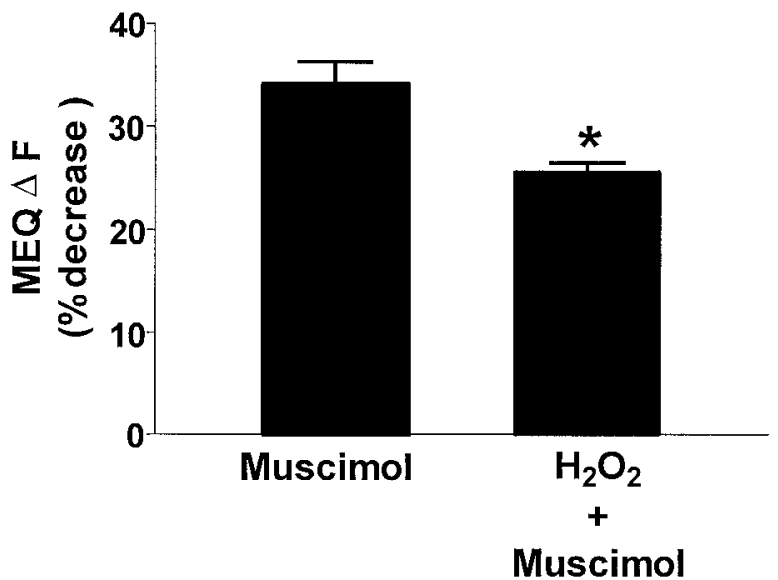

Figure 9. $\mathrm{H}_{2} \mathrm{O}_{2}$ attenuates the ability of muscimol to increase intracellular $\mathrm{Cl}^{-}$in area CA1 pyramidal cells. The $\mathrm{GABA}_{\mathrm{A}}$ agonist muscimol (50 $\mu \mathrm{M})$ was applied for $10 \mathrm{~min}$ to the chamber containing control slices or slices previously exposed to $10 \min _{2} \mathrm{H}_{2}$. The $\Delta F$ is the change in MEQ fluorescence after $10 \mathrm{~min}$ of exposure of control or peroxidized slices to muscimol. The $\Delta F$ for each cell was calculated as described in Materials and Methods, except the fluorescence intensity values before muscimol addition were used for the $F_{\mathrm{b}}$. Data are the mean \pm SEM of 7-14 cells from at least three slices per condition. ${ }^{*} p<0.05$ versus control; Student's $t$ test.

dependent $\mathrm{Cl}^{-}$transporters, and these transporters may become impaired because $\mathrm{H}_{2} \mathrm{O}_{2}$ can decrease the ATP/ADP ratio (Tretter et al., 1997). Our model precludes any significant effects of $\mathrm{H}_{2} \mathrm{O}_{2}$ directly on $\mathrm{GABA}_{\mathrm{A}}$ receptors, which have been reported to be sensitive to modulation by redox agents (Pan et al., 1995).

Hydrogen peroxide and other ROS alter synaptic inhibition, although the exact mechanisms are not known (Muller et al., 1993; Pellmar, 1995, Frantseva et al., 1998). A sustained increase in intracellular $\mathrm{Cl}^{-}$will decrease the $\mathrm{Cl}^{-}$gradient, and this should reduce subsequent $\mathrm{GABA}_{\mathrm{A}}$-mediated hyperpolarization. Our findings are consistent with this process; the ability of muscimol to induce $\mathrm{Cl}^{-}$influx was reduced after slices were exposed to $\mathrm{H}_{2} \mathrm{O}_{2}$. Similarly, tonic activation of $\mathrm{GABA}_{\mathrm{A}}$ receptors by "ambient" GABA has been shown to elevate the resting $\mathrm{Cl}^{-}$ permeability, and it causes a positive shift in the reversal potential for $\mathrm{Cl}^{-}$and a decrease in inhibitory transmission (Thompson and Gahwiler, 1989). Intense and repeated activation of $\mathrm{GABA}_{\mathrm{A}}$ receptors has also been reported to collapse the $\mathrm{Cl}^{-}$concentration gradient, leading to a positive shift in $E_{\mathrm{Cl}}$ and a depolarizing response to GABA (Lambert and Grover 1995). This process may be important in conditions such as anoxia. In fact, Katchman et al. (1994) showed that the anoxia-induced suppression of monosynaptic $\mathrm{GABA}_{\mathrm{A}}$ receptor IPSCs in CA1 pyramidal neurons was caused by an altered IPSC reversal potential. In our previous studies, we also found that oxygen-glucose deprivation in the hippocampal slice decreased GABA responses caused by increased $\left[\mathrm{Cl}^{-}\right] \mathrm{i}$ (Inglefield and Schwartz-Bloom, 1998). Thus, when neurons are exposed to oxidative stress, increases in intraneuronal $\mathrm{Cl}^{-}$may explain the reduction in synaptic inhibition mediated by $\mathrm{GABA}_{\mathrm{A}}$ receptors.

Using optical imaging techniques within the hippocampal slice, we have demonstrated that exposure of neurons to mild oxidative stress produced by $\mathrm{H}_{2} \mathrm{O}_{2}$ increases $\mathrm{Cl}^{-}$levels within hippocampal pyramidal cell soma but not in interneurons. Impairment of $\mathrm{Cl}^{-}$ 
gradients by $\mathrm{H}_{2} \mathrm{O}_{2}$ may reduce the efficacy of $\mathrm{GABA}_{\mathrm{A}}$ receptormediated inhibitory transmission and potentiate neurodegenerative damage in conditions such as Alzheimer's disease, Parkinson's disease, and aging.

\section{REFERENCES}

Alvarez-Leefmans FJ (1990) Intracellular $\mathrm{Cl}^{-}$regulation and synaptic inhibition in vertebrate and invertebrate neurons. In: Chloride channels and carriers in nerve, muscle, and glial cells (Alvarez-Leefmans FJ, Russell JM, eds), pp 109-158. New York: Plenum.

Auerbach JM, Segal M (1997) Peroxide modulation of slow onset potentiation in rat hippocampus. J Neurosci 17:8695-8701.

Beal MF (1995) Aging, energy and oxidative stress in neurodegenerative diseases. Ann Neurol 38:357-366.

Berman SB, Hastings TJ (1997) Inhibition of glutamate transport in synaptosomes by dopamine oxidation and reactive oxygen species. J Neurochem 69:1185-1195.

Bindokas VP, Jordán J, Lee CC, Miller RJ (1996) Superoxide production in rat hippocampal neurons: selective imaging with hydroethidine. J Neurosci 16:1324-1336.

Biwersi J, Verkman AS (1991) Cell-permeable fluorescent indicator for cytosolic chloride. Biochemistry 30:7879-7883.

Calabresi P, Centonze D, Pisani A, Sancesario G, Gubellini P, Marfia GA, Bernadi G (1998) Striatal spiny neurons and cholinergic interneurons express differential ionotropic glutamatergic responses and vulnerability: implications for ischemia and Huntington's disease. Ann Neurol 43:586-597.

Colton CA, Fagni L, Gilbert D (1989) The action of hydrogen peroxide on paired pulse and long-term potentiation in the hippocampus. Free Radic Biol Med 7:3-8.

Crain BJ, Westerkam WD, Harrison AH, Nadler JV (1988) Selective neuronal death after transient forebrain ischemia in the Mongolian gerbil: a silver impregnation study. Neuroscience 27:387-402.

Crow JP (1997) Dichlorodihydrofluorescein and dihydrorhodamine 123 are sensitive indicators of peroxynitrite in vitro: implications for measurement of reactive nitrogen and oxygen species. Nitric Oxide 1:145-157.

Dugan LL, Sensi SL, Canzoniero LMT, Handran SD, Rothman SM, Lin TS, Goldberg MP, Choi DW (1995) Mitochondrial production of reactive oxygen species in cortical neurons following exposure to $N$-methyl-D-aspartate. J Neurosci 15:6377-6388.

Frantseva MV, Jose L, Velazquez P, Carlan PL (1998) Changes in membrane and synaptic properties of thalamocortical circuitary caused by hydrogen peroxide. J Neurophysiol 80:1317-1326.

Gardner AM, Xu F-H, Fady C, Jacoby FJ, Duffey DC, Tu Y, Lichtenstein A (1997) Apoptotic vs nonapoptotic cytotoxicity induced by hydrogen peroxide. Free Radic Biol Med 22:73-83.

Gilman SC, Bonner MJ, Pellmar TC (1994) Free radicals enhance basal release of D- $\left[{ }^{3} \mathrm{H}\right]$ Aspartate from cerebral cortical synaptosomes. J Neurochem 62:1757-1763.

Haber F, Weiss J (1934) The catalytic decomposition of hydrogen peroxide by iron salts. Proc R Soc Lond B Biol Sci 147:332-351.

Halliwell B, Gutteridge JMC (1989) Free radicals in biology and medicine. New York: Oxford UP.

Hyslop PA, Zhang Z, Pearson DV, Phebus LA (1995) Measurement of striatal $\mathrm{H}_{2} \mathrm{O}_{2}$ by microdialysis following global forebrain ischemia and reperfusion in the rat: correlation with the cytotoxic potential of $\mathrm{H}_{2} \mathrm{O}_{2}$ in vitro. Brain Res 671:181-186.

Inglefield JR, Schwartz-Bloom RD (1997) Confocal imaging of intracellular chloride in living brain slices: measurement of $\mathrm{GABA}_{\mathrm{A}}$ receptor activity. J Neurosci Methods 75:127-135.

Inglefield JR, Schwartz-Bloom RD (1998) Optical imaging of hippocampal neurons with a chloride-sensitive dye: early effects of in vitro ischemia. J Neurochem 70:2500-2509.

Inglefield JR, Wilson CA, Schwartz-Bloom RD (1997) Effect of transient cerebral ischemia on $\gamma$-aminobutyric acid receptor $\alpha 1$-subunitimmunoreactive interneurons in the gerbil CA1 hippocampus. Hippocampus 7:511-523.

Katchman AN, Vicini S, Hershkowitz N (1994) Mechanism of early anoxia-induced suppression of the $\mathrm{GABA}_{\mathrm{A}^{-}}$mediated inhibitory postsynaptic current. J Neurophysiol 71:1128-1138.

Katsuki H, Nakanishi C, Saito H, Matsuki N (1997) Biphasic effect of hydrogen peroxide on field potentials in rat hippocampal slices. Eur J Pharmacol 337:213-218.
Kourie JI (1998) Interaction of reactive oxygen species with ion transport mechanisms Am J Physiol 275:C1-C24.

Lambert N, Grover L (1995) The mechanism of biphasic GABA responses. Science 269:928-929.

LeBel CP, Ischiropoulos H, Bondy SC (1992) Evaluation of the probe 2', $7^{\prime}$-dichloro-fluorescin as an indicator of reactive oxygen species formation and oxidative stress. Chem Res Toxicol 5:227-231.

Li A, Segui J, Heinemann SH, Hoshi T (1998) Oxidation regulates neuronal voltage-dependent $\mathrm{Ca}^{2+}$ channels expressed in Xenopus oocytes. J Neurosci 18:6740-6747.

Lindroth P, Mopper K (1979) High performance liquid chromatographic determination of picomole amounts of amino acids by precolumn derivatisation with $o$-phthaldialdehyde. Anal Chem 51:1667-1674.

Mattson MP (1998) Modification of ion homeostasis by lipid peroxidation: roles in neuronal degeneration and adaptive plasticity. Trends Neurosci 20:53-57.

Medina L, Figueredo-Cardenas G, Reiner A (1996) Differential abundance of superoxide dismutase in interneurons versus projection neurons and in matrix versus striosome neurons in monkey striatum. Brain Res 708:59-70.

Muller M, Fontana A, Zbinden G, Gahwiler BH (1993) Effects of interferons and hydrogen peroxide on CA3 pyramidal cells in rat hippocampal slice cultures. Brain Res 619:157-162.

Nitsch C, Goping G, Klatzo I (1989) Preservation of GABAergic perikarya and boutons after transient cerebral hippocampus in the gerbil CA1 hippocampal field. Neurosci Lett 495:243-252.

Oliveira CR, Agostinho P, Caseiro P, Duarte CB, Carvalho AP (1994) Reactive oxygen species on GABA release. Ann NY Acad Sci 738:130-140.

Pan ZH, Bahring R, Grantyn R, Lipton S (1995) Differential modulation by sulfhydral redox agents and glutathione of GABA- and glycineevoked currents in rat retinal ganglion cells. J Neurosci 15:1384-1391.

Pellegrini-Giampietro DE, Cherici G, Alesiani M, Carla V, Moroni F (1988) Excitatory amino acid release from rat hippocampal slices as a consequence of free-radical formation. J Neurochem 51:1960-1963.

Pellmar TC (1995) Use of brain slices in the study of free-radical actions. J Neurosci Methods 59:93-98.

Pellmar TC, Neel KL, Lee KH (1989) Free radicals mediate peroxidative damage in guinea pig hippocampus in vitro. J Neurosci Res 24:437-444.

Peterson CL, Thompson MA, Martin D, Nadler JV (1995) Modulation of glutamate and aspartate release from slices of hippocampal area CA1 by inhibitors of arachidonic acid metabolism. J Neurochem 64:1152-1160.

Rego AC, Santos MS, Oliveira CA (1996) Oxidative stress, hypoxia and ischemia-like conditions increase the release of endogenous amino acids by distinct mechanisms in cultured retinal cells. J Neurochem 66:2506-2516.

Reynolds IJ, Hastings TG (1995) Glutamate induces the production of reactive oxygen species in cultured forebrain neurons following NMDA receptor activation. J Neurosci 15:3318-3337.

Sah R, Schwartz-Bloom RD (1999) Imaging area CA1 hippocampal neurons in the brain slice after exposure to hydrogen peroxide: effects on intracellular chloride. J Neurochem [Suppl] 72:S34A.

Saransaari P, Oja SS (1998) Release of endogenous glutamate, aspartate, GABA, and taurine from hippocampal slices from adult and developing mice under cell-damaging conditions. Neurochem Res 23:563-570.

Satoh T, Tadahiro N, Yasuhiro A, Tomoko Y, Yasuyuki E, Hiroshi H (1998) Production of reactive oxygen species and release of L-glutamate during superoxide anion-induced cell death of cerebellar granule neurons. J Neurochem 70:316-324.

Schwartz RD, Skolnick P, Paul SM (1988) Regulation of $\gamma$-aminobutyric acid/barbiturate receptor-gated chloride ion flux in brain vesicles by phospholipase $\mathrm{A}_{2}$ : possible role of oxygen radicals. J Neurochem 50:565-571.

Simonian NA, Coyle JT (1996) Oxidative stress in neurodegenerative disease. Annu Rev Pharmacol Toxicol 36:83-106.

Sohal RS, Ku H, Agarwal S, Forster MJ, Lal H (1994) Oxidative damage, mitochondrial oxidant generation and antioxidant defences during aging and in food restriction in the mouse. Mech Ageing Dev 74:121-133.

Sperk G, Schwarzer C, Tsunashima K, Fuchs K, Sieghart W (1997) $\mathrm{GABA}(\mathrm{A})$ receptor subunits in the rat hippocampus. I. Immunocytochemical distribution of 13 subunits. Neuroscience 80:987-1000. 
Thompson SM, Gahwiler BH (1989) Activity-dependent disinhibition. II. Effects of extracellular potassium, furosemide, and membrane potential on ECl in hippocampal CA3 neurons. J Neurophysiol 61:512-523.

Tretter L, Adam-Vizi V (1996) Early events in free radical-mediated damage of isolated nerve terminals: effects of peroxides on membrane potential and intracellular $\mathrm{Na}^{+}$and $\mathrm{Ca}^{2+}$ concentrations. J Neurochem 66:2057-2066.

Tretter L, Chinopoulos C, Adam-Vizi V (1997) Enhanced depolarizationevoked calcium signal and reduced [ATP/ADP] ratio are unrelated events induced by oxidative stress in synaptosomes. J Neurochem 69:2529-2537.

Verkman AS (1990) Development and biological applications of chloride-sensitive fluorescent indicators. Am J Physiol 259:C375-C388.
Volterra A, Trotti D, Tromba C, Floridi S, Racagni G (1994) Glutamate uptake inhibition by oxygen free radicals in cortical astrocytes. J Neurosci 14:2924-2932.

Wilde GJC, Pringle AK, Wright P, Iannotti F (1997) Differential vulnerability of the CA1 and CA3 subfields of the hippocampus to superoxide and hydroxyl radicals in vitro. J Neurochem 69:883-886.

Xiang Z, Huguenard JR, Prince DA (1998) GABA receptor-mediated currents in interneurons and pyramidal cells of rat visual cortex. J Physiol (Lond) 506:713-730.

Yamada K, Goto S, Oyama T, Yoshikawa M, Nagahiro S, Ushio Y (1995) Striatal cells containing the $\mathrm{Ca}^{2+}$-binding protein calretinin (protein 10) in ischemia-induced neuronal injury. Acta Neuropathol (Berl) 89:172-177. 